\title{
Projection of Indonesian Islamic commercial banks efficiency and stability in the Covid-19 period using DEA and panel ARDL
}

\author{
M. Fikri Himmawan, Novian Abdi Firdausi \\ Islamic Economics Department, Faculty of Economics dan Business, \\ Universitas Airlangga, Surabaya, Indonesia
}

\begin{abstract}
Article History
Received : 10 September 2020

Revised : 2 December 2020

Accepted : 28 December 2020

Published : 11 January 2021
\end{abstract}

Keywords:

Covid-19, DEA, Efficiency, Panel

ARDL, Islamic Commercial Banks,

Stability

DOI:

https://doi.org/10.20885/JEKI.vol

7.iss1.art2

JEL Classification:

E32, G21, G28, G32, H84

Corresponding author:

himmawanfikri@gmail.com

Author's email:

novianfirdausi@gmail.com

Paper type:

Research paper

Cite this article:

Himmawan, M. F., \& Firdausi, N.A. (2021). Projection of Indonesian Islamic commercial banks efficiency and stability in the Covid-19 period using DEA and panel ARDL. Jurnal Ekonomi dan Keuangan Islam, 7(1), 17-30. https://doi.org/10.20885/JEKI.vol7.i ss1.art2

\section{Introduction}

The banking industry is one of the leading industries in the financial sector which act as an intermediary between the deficit spending units and the surplus spending units. This function should work well when deficit and surplus parties have persistent trust in the bank. Banks' intermediary function may strengthen a country's economic power, where banks as a financial institution are increasing their operational efficiency and financial optimization. Funds from the surplus parties will be collected by banks and then distributed to the deficit parties in the form of
Methodology - The DEA method analyses VRS and CRS scale using output orientation. The Panel ARDL also uses two models from the specifications in DEA, with the inputs as independent variables and the outputs as dependent variables.

Findings - The result of DEA is visualized in four quadrants from each CRS and VRS model. Respectively in each model, 1 and 5 banks are highly efficient and stable, 5 and 2 banks have high efficiency but low stability, 4 and 2 banks have low efficiency but high stability, 4 and 5 banks have low efficiency and stability. In the Panel ARDL, third party fund, operational expenses, and total financing have significant and stable long-run effect in both models. In the short-run, only operational expenses significantly affect operational earnings, whereas only total financing significantly affects total assets.

Practical implications - Banks may use strategies such as absorbing workforces as marketing representatives, utilizing cooperative provisions on expected credit loss, and deferring profit.

Research limitations - The limitation of this study is the small sample size because only 14 Islamic commercial banks are used as the sample, without considering the Islamic business units of the conventional banks so the predictive strength of the result only constrained in the Islamic commercial banks.

Originality - The study uses two different methods in assessing Islamic Commercial Banks especially in the Covid-19 period, hence adding insights on Islamic Commercial Banks in the pandemic period and further contributes to the Islamic banking field of study.

\begin{abstract}
Purpose - This study aims to assess the efficiency and stability of Indonesia Islamic Commercial Banks, and then the results are used as a projection in the Covid-19 period. It uses the sample from 14 Islamic Commercial Banks in Indonesia and its quarterly data from 2017 to 2020.
\end{abstract} agreements, crowdfunding, improving banking technology, creating 
productive activities. The productive activities will create outputs and absorb workforces which may increase public's income and wellbeing.

Indonesian Government Law No. 21 of 2008 on Islamic Banking stated that Indonesia is using dual banking system, which consisted of conventional and Islamic banks. Islamic banks are entities which carry out business activities under Sharia or Islamic legal principles as regulated in the fatwas of Indonesian Ulema Council (MUI). A summary of the fatwas requires Islamic banks to operate with the principles of welfare (maslaha), justice and balance ('adl wa tawazun), and universalism. Banks operation must also not contain gharar, usury, maisir, wrongdoings, and haram objects. Additionally, Islamic banking law also requires Islamic banks to perform social functions just like Bayt al-mal institution which collect funds from alms, donations, waqf, and zakat (Sodikin, 2020).

Since the advent of Islamic banks, Islamic financial services at the national level are expected to strengthen the aggregate economic growth in Indonesia, especially in the last two decades. It applies the same for the achievement and growth, governance, supporting infrastructure, regulation, surveillance, and public awareness on Islamic financial services. Until April 2020, the industry of Islamic commercial banks, in particular, had the total asset of IDR 348,294 billion, profit of IDR 5,404 billion, total third party fund customers of 22,871,337, and financing, receivables, ijarah, and salam customers of 4,132,034 customers (OJK, 2020).

However, Indonesian economy is overshadowed by the recent Covid-19 outbreak. According to a report by National Committee for Islamic Economy and Finance (2020) on the impacts of Covid-19 on OIC countries' Islamic finance, Indonesia has had a fatality rate of $7.58 \%$ and considered as one of the highest in the world. Indonesian Rupiah to U.S. Dollar exchange rate on March 23 touched 16,575 Rupiah per 1 U.S. Dollar, the weakest level since the financial crisis of 1998. Indonesian Stock Exchange (IDX) is also getting struck by Covid-19 outbreak, Jakarta Composite Index had a comfortable and steady value around 6,200 as of late January 2020 then plummeted to around 4,000 in late March before rebounded to 4,500 in early April. Indonesian Gross Domestic Product (GDP) is expected to recover around 2021 with an approximate growth of 5.2-5.6\%. In summary, the Indonesian economy and finance will have a period of slowdown.

Before the pandemic struck, Indonesian Islamic banks maintained a stable performance with business financing recorded at IDR 195.3 trillion, with the top three sectors being wholesale and retail trade (18.7\%), construction (15.8\%), and manufacturing (13.6\%). Covid-19 lowers manufacturing productions, delays and/or cancellation on projects, and reduces demands on non-digital markets (retail or wholesale). This made related parties unable to fulfill their payment obligations. As per the instruction from the Indonesian Financial Service Authority (OJK), financial restructuring is vital to ensure those affected by the pandemic are not burdened by any additional financial constraints due to their inability to pay within the economic slowdown (Hidayat et al., 2020). In this condition, the Islamic banking industry is required to evaluate and improve comprehensively, especially the fundamental operation to survive the ever-changing economic condition. Analysis on the efficiency of Islamic commercial banks may become a benchmark as less controlled expansive activities will result in personnel burden and fixed asset over target. Moreover, expansive collection and distribution of funds without considering efficiency factor will affect a bank's profitability (Yulita \& Rizal, 2016).

Existing literature on Covid-19 and its effects in Islamic banks are relatively limited as the Covid-19 pandemic is still in effect and lots of researches are still ongoing. A recent study by Sumarni (2020) stated that Covid-19 may suppress Indonesian economic growth by $2.3 \%$ in 2020. Furthermore, Ningsih \& Mahfudz (2020) found that as of January 2020, with 1,922 units of Islamic commercial banks across Indonesia and mostly located in Java Island, inferring that the majority of Islamic commercial banks are in the 'red zone' of the pandemic.

The intermediary function of Islamic banks requires banks to intermediate the meeting between investors and people in need of funds, so it is more likely that Islamic banks will face the difficulty. Even though the legal procedure may be made easy with the online system, the resulting effect of the pandemic in the economy may increase the difficulty in raising investments 
and funds. Related with the abovementioned condition, the assessment of Islamic banks efficiency will become important as efficiency reflects a firm's performance and considered as a concerning factor for stakeholders in formulating rational strategic decisions to reduce the risk level of banking operation. Owing to the fact that Covid-19 had hit Indonesia and affecting the financial industry, this study is driven by the intrigue of how well Islamic banking industry will survive through the pandemic.

\section{Literature Review}

Efficiency is a form of analysis on the relationship of produced outputs with the inputs. Farrell (1957) postulated that efficiency consisted of two components, namely allocative efficiency and technical efficiency. Allocative efficiency explains the firm's capability to optimize its inputs, production technology, and price structure. While technical efficiency explains firm's proficiency to generate output from a number of available inputs. These two measurements then combined into economic efficiency.

Theoretically, there are several approaches in measuring bank efficiency which are the production approach, the intermediation approach, the value-added approach, and the user cost approach. The core function of a financial intermediary usually defined as collecting funds from surplus spending units and distributing them to deficit spending units (Fama, 1980). To elaborate, Ahn \& Le (2014) summarized and broke down the role of bank's intermediary purpose from its risks.

The first is liquidity risk, defined as the difference in loan maturity and its size between creditors and depositors. Depositors tend to lend a smaller amount of money for a shorter time period than the borrowers' requirement. Banks as an intermediary acts as households' liquidity insurer against shocks that may affect households' consumption needs. Regarding size conflict, banks may alter financing size through accumulating funds from small-sized deposits then giving larger sized loans as banks have accesses to a large number of lenders than individual borrowers. With regard to maturity conflict, banks may invest in highly liquid assets with a large amount to solve the liquidity demand in the short-run. Concurrent with the role of liquidity insurer, banks may also use the accumulation of small depositor funds and lending it to invest in efficient projects on other entities, hence supporting the economic system's productivity. Looking through the economics of scale, it can be emphasized that banks' roles have an enormous economic impact just utilizing its intermediary function.

The second is credit risk, defined as the likelihood of borrowers' inability to return what they owed. Banks may reduce individual loan risks by monitoring and specifying borrowers, employing reserves on loan loss, and portfolio diversifications. Banks are considered as delegated monitors or qualitative asset transformers in this case. In the economic sense, the transformation process is interpreted as creating outputs of higher value than the original inputs. So the intermediation approach gains the widest application in bank efficiency studies and relatively superior to other approaches in evaluating the bank performance at the institutional level (Ahn \& Le, 2014).

Efficiency measurement has two general approaches, the non-parametric approach based on linear-programs and the parametric approach based on econometric techniques. The distinguishing factors from those two approaches are the limiting efficiency of assumptions and random error assessments (Mokhtar et al., 2006). The widely used method of non-parametric efficiency measurement is the Data Envelopment Analysis (DEA) (Fauzi, 2018). DEA is a technique of mathematical programming that calculates the efficiency of decision-making units in comparison with the similar decision-making units in which all of these units are line on or below its efficient frontier curve (Anwar, 2016).

DEA has two models, namely the Constant Return to Scale (CRS) and Variable Return to Scale (VRS) model. Charnes et al. (1978) proposed the CRS model which specifies that the proportional change in input level will result in the same proportionate change in the output level. The CRS model has a weakness that the model is only appropriate when all decisionmaking units (DMUs) are operating at an optimal scale. The existence of imperfections such as 
competition and constraints on finance made the DMUs do not operate at optimal scale (Coelli et al., 1998). Banker et al. (1984) proposed Variable Return to Scale (VRS) as an extension to the CRS model since non-optimal DMUs operations in the CRS will make the technical efficiency be confounded by scale efficiency. The VRS model makes the technical efficiency calculation unconstrained by scale efficiency effects. Furthermore, there are 2 orientations to calculate DEA models, the input-oriented, and the output-oriented measurement. Coelli et al. (1998) posited that input-oriented measurement calculates the number of inputs that can be proportionally reduced without changing the number of outputs produced. The output-oriented measurement is basically the opposite, it shows the number of outputs which can be increased proportionally without changing the number of inputs in use.

A study conducted by Yulita \& Rizal (2016) showed that Indonesian Islamic banks are more efficient than Malaysian Islamic banks in the period of the first quarter of 2011 until the fourth quarter of 2014, the analysis were done using DEA with the inputs of third party funds (DPK), fixed assets, and operational costs, with the outputs of total financing and total operating income. Another study conducted by Rodoni et al. (2017) found that Indonesian and Malaysian Islamic Banking Industry is inefficient and the banks' condition in Indonesia is worse than Malaysia, their study is also using DEA as the method to measure efficiency within five years average of 2009-2013. The DEA estimation uses fixed cost, staff cost, and total deposit as inputs, and the outputs are incomes, total loans, and liquid assets. The conclusion is that Indonesian Islamic Banks are in the range of $87 \%-97 \%$ efficiency rate while Malaysian banks are in the range of $92 \%-95 \%$, and the major causes of inefficiency are suspected to be external factors.

Banks have a varying degree of strategies to recollect their money, the application is also specifically unique depending on the individual bank's policies. The majority of borrowers are always willing to pay, but certain situations like inflation, economic recession, poor investment, and political instability makes them unable to pay (Offiong \& Egbuka, 2017). As the pandemic of Covid-19 struck Indonesia, the need to assess the long-term projection in the Covid-19 period becomes urgent.

Autoregressive Distributed Lag (ARDL) framework distinguishes between short-term and long-term impacts. The panel ARDL derives most of its merits from the traditional ARDL model. Including simultaneous estimation on short and long-run dynamics, while using different lags on different variables, it also complies with both large and small sample sizes. Due to a small sample time period, estimating a separate empirical equation for each bank in the sample is not optimal. As a result, it is more appropriate to use panel estimation as it is more suitable where data availability is limited. Panel estimation uses both time and cross-sectional dimensions and so increases the total number of observations and their variation. Moreover, panel estimation decreases the noise that comes from individual time-series estimation. This leads to a more reliable inference (Attard, 2019; Magweva \& Sibanda, 2020). Additionally, ARDL has the advantage in the mixed integration level of first difference $(\mathrm{I}(1))$ and level $(\mathrm{I}(0))$ as well as purely $\mathrm{I}(0)$ or $\mathrm{I}(1)$. The error correction model $(\mathrm{ECM})$ can integrate short-run adjustment and long-run equilibrium (Lu, 2019).

Prior study conducted by Iqbal (2017) defined that in assessing risk and stability of banks, Autoregressive Distributed Lag (ARDL) method could be used. Using the banking performance indicator such as third party funds growth, financing growth, and problem financing. The result is all identified factors could be used as indicators in credit risk control of both Islamic and conventional banks. Widarjono (2020) also used ARDL as a method to assess the Islamic banks stability in Indonesia covering from January 2010 to December 2018, the stability variable is measured through Non-Performing Financing (NPF) and Z-score, then adding firm size and Capital Adequacy Ratio (CAR) as firms' specific variables. The results are higher CAR, efficiency, and firm size may support banks' stability. From the overall literature section, the hypothesis to test the Panel ARDL is formulated as follows:

H1: Third party fund, operational cost, and total financing significantly influence Islamic commercial banks' operational earning in both long-run and short-run. 
H2: Third party funds, operational costs, and total financing significantly influence Islamic commercial banks' total assets in the long-run and short-run.

\section{Research Methods}

Using a quantitative approach with Data Envelopment Analysis (DEA) to assess efficiency and stability, the study also used Autoregressive Distributed Lag (ARDL) as further projection analysis in the short-term and long-term. This study uses secondary data from Islamic commercial Banks' quarter reports from the first quarter of 2017 to the second quarter of 2020. Samples were chosen through purposive sampling method, using Islamic commercial banks which are listed and supervised by the Indonesian Financial Services Authority (OJK). In total, 14 Islamic commercial Banks are analyzed, the description of the banks are summarized in Table 1.

Even though Indonesian Covid-19 outbreak happens in 2020, the starting timeframe is from the first quarter of 2017. This is due to the consistency of the data source, before 2017 the list of Islamic commercial banks are disparate, using further backwards timeframe or only using 2020 timeframe would only make the data becoming more biased. 2017-2019 shows upward trend while in 2020 shows mixed trends, several banks are stagnant while others have downward trends, thus examines whether the volatility projection still stable or not in the long run.

The DEA method uses Constant Return to Scale (CRS) and Variable Return to Scale (VRS). CRS efficiency assumes that the change of value in the inputs is also proportional to the change in the outputs. Adversely, VRS efficiency assumes that changes in outputs are not proportional to the changes in the inputs, the resulting outputs may be smaller or larger than the inputs (Yulita \& Rizal, 2016). This study uses output-oriented calculation with input variables consist of third party funds (DPK), operational cost (BIOP), and total financing (TFUND). While the output variables used are operational earning (PENDOP) and total asset (TASSET).

Table 1. Sample Description

\begin{tabular}{cl}
\hline No. & Islamic Commercial Banks \\
\hline 1 & Bank Syariah Mandiri (BSM) \\
2 & Bank Rakyat Indonesia Syariah (BRIS) \\
3 & Bank Negara Indonesia Syariah (BNIS) \\
4 & Bank Central Asia Syariah (BCAS) \\
5 & Bank Muamalat Indonesia (BMI) \\
6 & Bank Panin Syariah (BPS) \\
7 & Bank Syariah Bukopin (BSB) \\
8 & Bank Mega Syariah (BMS) \\
9 & Bank Victoria Syariah (BVS) \\
10 & Bank Pembangunan Daerah Nusa Tenggara Barat Syariah (BPD NTBS) \\
11 & Bank Tabungan Pensiunan Nasional Syariah (BTPNS) \\
12 & Bank Aceh Syariah (BAS) \\
13 & Bank Pembangunan Daerah Jawa Barat dan Banten Syariah (BJBS) \\
14 & Maybank Syariah (MS) \\
\hline Source: (Adapted from OJK, 2020)
\end{tabular}

The ARDL method uses panel ARDL with Pooled Mean Group (PMG) specification to combine both averaging and pooling of coefficients. This panel method allows the intercepts, short-run coefficients, and error variances to differ freely across groups (Attard, 2019). PMG also provides consistent coefficients despite the possible presence of endogeneity because they include the lags of dependent and independent variables. The PMG is a more middle-of-the-road approach to heterogeneous panel data estimation than Mean Group (MG) and Dynamic Fixed Effect (DFE) specification (Magweva \& Sibanda, 2020).

The use of this method encompasses the individual bank's effect and further contributes to the novelty of the study. In comparison, Widarjono (2020) who used ARDL as a method to assess the Islamic banks' stability in Indonesia used aggregate value of all Islamic commercial 
banks and Islamic business units, eliminating the possibilities of banks' individual effects. The variables in ARDL use the existing DEA variables, which mean that two-equation models as the output variables in DEA consist of two variables.

The first model in panel ARDL uses operational earning (PENDOP) as the dependent variable, while the second model uses total assets (TASSET) as the dependent variable. Before proceeding through ARDL, the cross-sectional dependence and unit root test are required as prerequisite testing, followed by estimating the panel ARDL for the long-run and short-run effects. Panel co-integration and Hausman tests are also conducted to provide model robustness. The panel ARDL model uses Equation 1 as follows:

$\Delta \ln Y_{i t}=\varphi_{1} \ln \left(Y_{i t-1}\right)+{B^{\prime}}_{1} \ln \left(X_{i t-1}\right)+\sum_{j=1}^{p-1} V_{i j} \Delta \ln \left(Y_{i, t-j}\right)+\sum_{j=0}^{q-1} \theta_{i j}^{\prime} \Delta \ln \left(X_{i, t-j}\right)+\eta_{i t}$

The study adopts the equation from Pesaran et al. (1999) and Bardi et al. (2019) for easier description of ARDL (p, q), where $Y$ is the dependent variable (PENDOP) and TASSET), $X$ is a list of independent variables (DPK, BIOP, and TFUND). $V$ and $\theta$ represent the short-run coefficients of lagged dependent and independent variables respectively, $B$ and $\varphi$ represent the long-run coefficients and speed adjustment to long-run steady-state coefficient respectively, $\eta$ is the banks' specific intercept, $i$ and $t$ represent bank and time respectively.

\section{Results and Discussion}

Table 2. Descriptive Statistics

\begin{tabular}{ccccc}
\hline Variables & Minimum & Maximum & Mean & Std. Deviation \\
\hline PENDOP & 7,506 & $5,747,030$ & 728,952 & $1,048,281$ \\
TASSET & 659,857 & $114,746,985$ & $22,094,329$ & $26,479,488$ \\
DPK & 16,823 & $101,915,689$ & $18,250,963$ & $23,203,325$ \\
BIOP & 2,130 & $4,460,319$ & 562,358 & 802,223 \\
TFUND & 58,867 & $75,445,553$ & $14,597,575$ & $17,916,196$ \\
\hline
\end{tabular}

Source: (Data processing)

The descriptive statistics is using million Rupiahs as the base unit since financial reports are in thousands or millions so the standard deviation is also in the hundreds of thousands. Since Islamic commercial banks are having mixed ownership, state-owned banks commonly have bigger value in all variables. The news on large scale government project to merge state-owned Islamic banks to become a super-holding also contributes to the big maximum value, three Stateowned Banks Association (Himbara) member namely Bank BRI Syariah, Bank BNI Syariah, and Bank Mandiri Syariah (BSM) had signed Conditional Merger Agreement (CMA) related to the merger plan of Islamic Commercial Banks (Sulaeman, 2020). Adversely, private-owned banks majorly contribute to the minimum value, hence the disparity between the state-owned and private-owned banks further contribute to the deviation level.

\section{DEA Analysis}

In Figure 1, Islamic commercial banks are dispersed around all quadrants. The first quadrant shows banks with high efficiency and stability, only BAS is in this quadrant. The second quadrant consists of banks with high efficiency but low stability, including BRIS, BMI, BVS, BPD NTBS, and BTPNS. The third quadrant defines banks with low efficiency and high stability, comprised of BSM, BNIS, BCAS, and BMS. Lastly, the fourth quadrant contains BPS, BSB, BJBS, and MS as banks with low efficiency and stability.

After analyzing the CRS model, the following analysis is the VRS model. The comparison between CRS and VRS is needed as CRS only measures the outputs which are proportional to available inputs, expressing a constraint between outputs and inputs. Different from the CRS model, the VRS model puts forward the variables (Alfarisi \& Lukman, 2019). In the outputoriented specification, VRS will assess the inputs to maximize the available outputs.

From Figure 2, the first quadrant which shows banks with high efficiency and stability is composed of BSM, BRIS, BMI, BPD NTBS, and BAS. The second quadrant consists of banks 
with high efficiency but low stability, including BVS and BTPNS. The third quadrant defines banks with low efficiency and high stability, comprised of BNIS and BCAS. Lastly, the fourth quadrant contains BPS, BSB, BMS, BJBS, and MS as banks with low efficiency and stability.

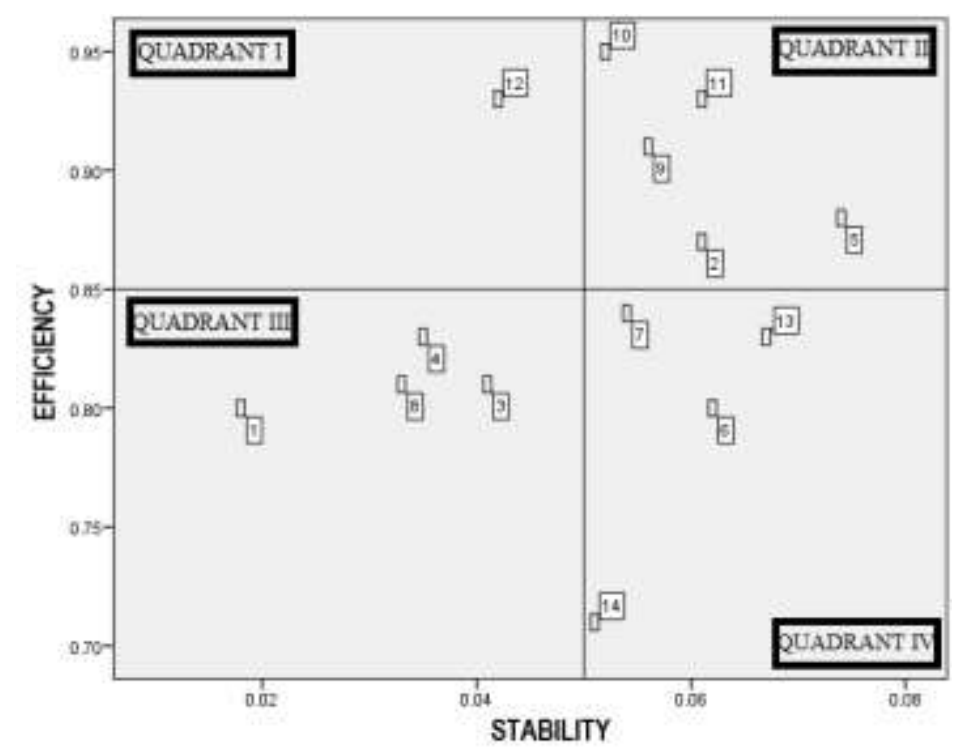

Source: (Data processing)

Figure 1. Constant Return to Scale (CRS) Quadrants

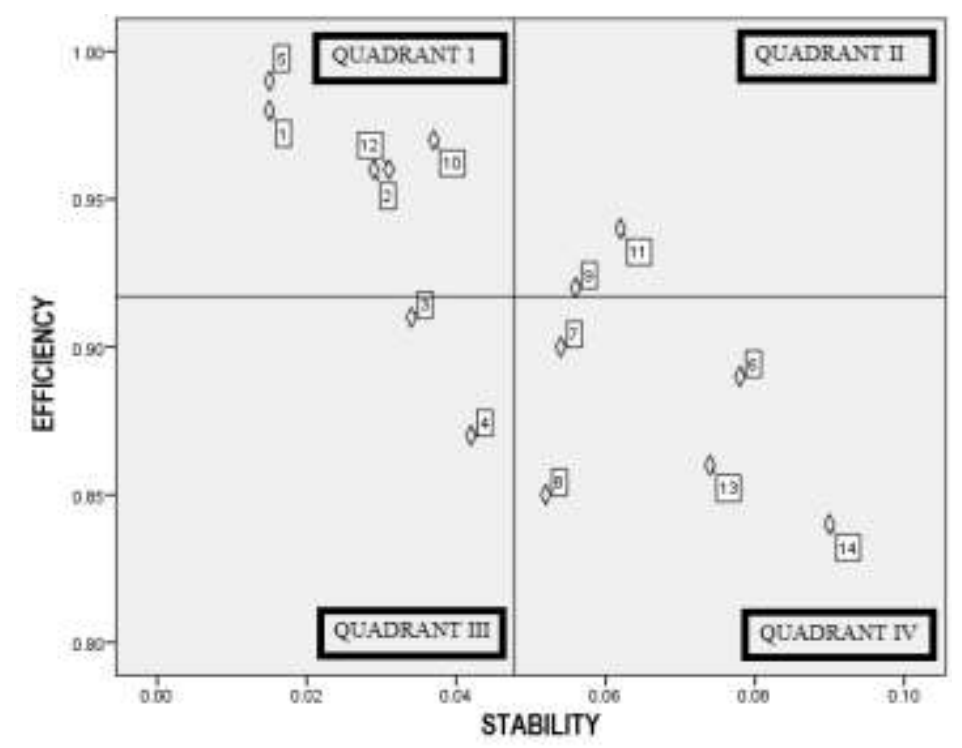

Source: (Data processing)

Figure 2. Variable Return to Scale (VRS) Quadrants

Table 3 summarized the mean value and standard deviation of each banks from the quarterly data used in the study. The mean value represent the efficiency level. Table 3 shows that the average of mean value on the CRS and the VRS models are 0.85 and 0.92 respectively. It can be inferred that Islamic Commercial Banks are having 85\% average efficiency if assessed with the CRS model, with MS have the lowest average while BPD NTBS have the highest. In the VRS model, Islamic commercial banks are having 92\% average efficiency, while BJBS has the lowest average and BMI has the highest average value.

The standard deviation represents the risk level experienced by Islamic commercial banks, while low standard deviation infers strong stability in responding shocks from efficiency factors. The average standard deviation on the CRS and the VRS models are only about $5 \%$ and $4.8 \%$ respectively. It is noticeable that BSM and BMI have the lowest standard deviation value 
both in the CRS and VRS model. Meanwhile, the highest standard deviation in CRS is placed by BMI, while MS has the highest standard deviation in the VRS model.

Table 3. CRS and VRS Summary

\begin{tabular}{lcccc}
\hline \multirow{2}{*}{ Unit Name } & \multicolumn{2}{c}{ CRS } & \multicolumn{2}{c}{ VRS } \\
\cline { 2 - 5 } & Mean & Std. Dev. & 0.98 & Std. Dev. \\
\hline BSM & 0.80 & 0.018 & 0.96 & 0.015 \\
BRIS & 0.87 & 0.061 & 0.91 & 0.029 \\
BNIS & 0.81 & 0.041 & 0.87 & 0.034 \\
BCAS & 0.83 & 0.035 & 0.99 & 0.015 \\
BMI & 0.88 & 0.074 & 0.89 & 0.078 \\
BPS & 0.80 & 0.062 & 0.9 & 0.054 \\
BSB & 0.84 & 0.054 & 0.85 & 0.052 \\
BMS & 0.81 & 0.033 & 0.92 & 0.056 \\
BVS & 0.91 & 0.056 & 0.97 & 0.037 \\
BPD NTBS & 0.95 & 0.052 & 0.94 & 0.062 \\
BTPNS & 0.93 & 0.061 & 0.96 & 0.031 \\
BAS & 0.93 & 0.042 & 0.86 & 0.074 \\
BJBS & 0.83 & 0.067 & 0.84 & 0.09 \\
MS & 0.71 & 0.05 & 0.92 & 0.048 \\
\hline AVERAGE & 0.85 & 0.05 & & \\
\hline SOHCe: (Data & & & & \\
\hline
\end{tabular}

Source: (Data processing)

\section{Panel ARDL Analysis}

The first prerequisite test for panel ARDL is cross-section dependence (CSD), using BreuschPagan LM, Pesaran LM, Bias-corrected LM, and Pesaran CD as the instruments. All results in Model 1 and 2 are significant under 1\% significance level, meaning that there exists strong crosssection dependence. The results call for the second generation unit root test for using the first generation test only will produce biased results, as the first generation assumes all variables are independent of others' cross-section. The second-generation unit root test relaxes this restriction.

Table 4. Unit Root Test

\begin{tabular}{|c|c|c|c|c|}
\hline \multirow{3}{*}{ Variables } & \multicolumn{4}{|c|}{ First Generation } \\
\hline & \multicolumn{2}{|c|}{ Level } & \multicolumn{2}{|c|}{ First Difference } \\
\hline & IPS & LLC & IPS & LLC \\
\hline PENDOP & $-11.294^{* * *}$ & $-10.802^{* * *}$ & $-8.597 * * *$ & $-12.843^{* * *}$ \\
\hline TASSET & 1.739 & 0.165 & $-10.986^{* * *}$ & $-11.488^{* * *}$ \\
\hline DPK & 1.077 & -0.734 & $-10.113^{* * *}$ & $-12.137 * * *$ \\
\hline BIOP & $-12.747 * * *$ & $-11.759 * * *$ & $-8.708^{* * *}$ & $-13.023^{* * *}$ \\
\hline TFUND & 0.984 & -0.563 & $-6.289 * * *$ & $-8.884 * * *$ \\
\hline \multicolumn{5}{|c|}{ Second Generation } \\
\hline \multirow{2}{*}{ Variables } & \multicolumn{2}{|c|}{ Level } & \multicolumn{2}{|c|}{ First Difference } \\
\hline & CADF & CIPS & CADF & CIPS \\
\hline PENDOP & -1.501 & -1.253 & $-2.527 * *$ & $-3.224 * * *$ \\
\hline TASSET & $-2.298 * *$ & $-2.856^{* * *}$ & $-2.559 * * *$ & $-3.811 * * *$ \\
\hline DPK & $-2.339 * *$ & $-2.296 * *$ & $-2.248^{* *}$ & $-3.858 * * *$ \\
\hline BIOP & -1.136 & -1.571 & $-2.381 * *$ & $-3.909 * * *$ \\
\hline TFUND & -1.029 & -1.187 & $-2.664 * * *$ & $-2.675^{* * *}$ \\
\hline
\end{tabular}

Note: ${ }^{*}, *$, and ${ }^{* * *}$ denote significance at $10 \%, 5 \%$, and $1 \%$, respectively

Source: (Data processing)

The Im-Pesaran-Shin (IPS) test is used as an additional benchmark for the IPS test which has less restrictive assumptions on cross-sectional homogeneity and serial correlation (Lu, 2019). Both the IPS and Levin-Lin-Chu (LLC) do not consider the cross-section dependency problem which emerges from unobserved common factors, unaccounted residual independence, and 
macroeconomic conditions. Thus, both are categorized as the first-generation test. In the presence of cross-sectional dependence, the Pesaran's (2007) cross-sectional Augmented DickeyFuller (CADF) and cross-sectional IPS (CIPS) tests are conducted.

The second-generation unit root tests ensure that even cross-sectional dependency is present, the variables are still co-integrated in either level or first difference (Attard, 2019). From the second-generation unit root test, it could be inferred that the co-integration levels of the respective variables are mainly unchanged, with the varying co-integrations are still at the level and first difference, proving the robustness of the data.

Table 5. Panel Co-integration Test

\begin{tabular}{|c|c|c|c|c|c|c|}
\hline \multirow{4}{*}{ Instrument } & \multicolumn{5}{|c|}{ Pedroni Test } & \\
\hline & \multicolumn{3}{|c|}{ First Model } & \multicolumn{3}{|c|}{ Second Model } \\
\hline & \multicolumn{2}{|c|}{ Within Dimension } & \multirow{2}{*}{$\begin{array}{c}\text { Between } \\
\text { Dimension } \\
\text { Statistic }\end{array}$} & \multicolumn{2}{|c|}{ Within Dimension } & \multirow{2}{*}{$\begin{array}{c}\text { Between } \\
\text { Dimension } \\
\text { Statistic }\end{array}$} \\
\hline & Statistic & $\begin{array}{l}\text { Weighted } \\
\text { Statistic }\end{array}$ & & Statistic & $\begin{array}{c}\text { Weighted } \\
\text { Statistic }\end{array}$ & \\
\hline v-statistic & -0.772 & -2.155 & & -0.033 & -0.508 & \\
\hline$\rho$-statistic & 1.567 & 2.027 & 3.854 & 1.116 & 1.121 & 2.151 \\
\hline PP & $-5.862 * * *$ & $-1.973^{* *}$ & $-3.295 * * *$ & $-3.253 * * *$ & $-2.755^{* * *}$ & $-5.998 * * *$ \\
\hline $\mathrm{ADF}$ & $-5.151 * * *$ & $-3.307 * * *$ & $-4.047 * * *$ & $-3.528 * * *$ & $-3.098 * * *$ & $-4.626 * * *$ \\
\hline \multicolumn{7}{|c|}{ Kao Test } \\
\hline $\mathrm{ADF}$ & & $-10.156^{* * *}$ & & & $-4.406 * * *$ & \\
\hline
\end{tabular}

Note: $* * *$, and $* * *$ denote significance at $10 \%, 5 \%$, and $1 \%$, respectively

Source: (Data processing)

The Pedroni panel co-integration test in both models is dominantly significant from the eleven instruments used in each model. Concurrently, the Kao test also provides significant results for both models. In summary, both Pedroni and Kao tests prove the stability of the long-run effects. The comparative Hausman tests verify the PMG as the best specification. If the null hypothesis is rejected, then the best specification should be the mean group (MG) or ordinary least square (OLS). The result of the first model has a chi-square of 1.23 with a significance value of 0.75 , while the second model has a chi-square of 2.32 with a 0.51 significance value. In summary, PMG specification is best used on both models (Model 1 and 2), proving further robustness. All the panel ARDL estimation use the optimal lag under the Schwarz Information Criterion.

Table 6. Panel ARDL Estimation Result

\begin{tabular}{|c|c|c|c|c|}
\hline \multicolumn{5}{|c|}{ Long Run Results } \\
\hline \multirow{2}{*}{ Variables } & \multicolumn{2}{|c|}{ First Model } & \multicolumn{2}{|c|}{ Second Model } \\
\hline & Coefficient & Significance & Coefficient & Significance \\
\hline $\mathrm{DPK}$ & -0.3747 & $0.000 * * *$ & 0.3309 & $0.000^{* * *}$ \\
\hline BIOP & 0.8559 & $0.000^{* * *}$ & -0.3821 & $0.000 * * *$ \\
\hline TFUND & 0.9497 & $0.000 * * *$ & -0.3425 & $0.000 * * *$ \\
\hline \multicolumn{5}{|c|}{ Short Run Results } \\
\hline \multirow{2}{*}{ Variables } & \multicolumn{2}{|c|}{$\begin{array}{l}\text { First Model } \\
\end{array}$} & \multicolumn{2}{|c|}{ Second Model } \\
\hline & Coefficient & Significance & Coefficient & Significance \\
\hline ECT & -0.5496 & $0.001 * * *$ & -0.1207 & $0.018^{* *}$ \\
\hline$\triangle \mathrm{PENDOP}_{\mathrm{t}-1}$ & 0.3007 & 0.103 & & \\
\hline$\Delta \mathrm{TASSET}_{\mathrm{t}-1}$ & & & -0.2473 & 0.294 \\
\hline$\triangle \mathrm{DPK}$ & 0.2603 & 0.293 & 0.151 & 0.256 \\
\hline$\Delta \mathrm{DPK}_{\mathrm{t}-1}$ & 0.1321 & 0.806 & 0.1054 & 0.314 \\
\hline$\triangle \mathrm{BIOP}$ & 0.4295 & $0.005^{* * *}$ & 0.004 & 0.15 \\
\hline$\Delta \mathrm{BIOP}_{\mathrm{t}-1}$ & 0.0137 & 0.453 & 0.0015 & 0.062 \\
\hline$\Delta$ TFUND & -0.0829 & 0.813 & 0.2733 & $0.004 * * *$ \\
\hline$\Delta$TFUND $_{\mathrm{t}-1}$ & -0.6301 & 0.22 & 0.0388 & 0.697 \\
\hline Constant & -3.8498 & $0.001 * * *$ & 0.0371 & 0.184 \\
\hline
\end{tabular}

Note: $*, * *$, and $* * *$ denote significance at $10 \%, 5 \%$, and $1 \%$, respectively

Source: (Data processing) 
Table 6 shows Panel ARDL results. In the first model when the operational earning (PENDOP) acts as dependent variable, third party fund (DPK) is projected to reduce operational earnings, where the operational expense (BIOP) and total financing (TFUND) are projected to increase operational earnings. In the second model when the total asset (TASSET) acts as the dependent variable, the operational expense (BIOP) and third party fund (DPK) are projected to reduce total assets. The short-run results show that only operational expense (BIOP) significantly influences operational earning (PENDOP) and only total financing (TFUND) significantly influences total asset (TASSET). The Error Correction Term (ECT) shows the speed of adjustment of the last period's short-run error will be adjusted in the current period and it will reach the equilibrium in less than 2 quarter periods in the first model, whereas in the second model the equilibrium will be reached in less than 9 quarter periods.

\section{Overall Analysis}

Islamic banking in Indonesia as of July 2020 only owned $9.68 \%$ of the total assets of the banking industry $(\mathrm{OJK}, 2020)$. A challenge to maximize the performance of Islamic banks to overtake its conventional competitors requires strategies to increase total assets and services provided to customers and prospective customers, one of which is through digitization and efficiency of banking services. The phenomenon of digitalization can minimize inputs because banks are not required to open branches and to maximize service usage through smartphones in transactions, this benefit is in line with the policy in POJK No.19/POJK.03/2014 concerning Officeless Banking Service in the Framework of Financial Inclusion. The input represented from these costs can maximize output, which in this case is reflected by operating income and total assets. The existence of countercyclical policy (officeless banking) as a series of digitalization in the financial and banking sector is expected to foster financial inclusiveness.

Islamic Commercial Banks that have the efficiency value under the average mean score, or therefore categorized as inefficient, can increase their inputs. Third-party funds and total financing can be increased through contemporary products such as mudarabah sukuk and ijara muntabia bi tamleek. (IMBT) for asset financing. Bank efficiency can be improved by reducing operational expenses as the input value and maintaining the same output level. However, the operational expense which logically should be reduced to increase the operational earning and total asset, can be construed as bigger operational expense signifies workforce absorption Hidayat et al (2020). They further explained that the increase in absorbed workforce will increase a country's economic power especially in the hard time due to pandemic. The workforce can be focused to work as a fundraiser or marketing representative hence increasing the possibility of bigger total financing and third-party funds in the future.

Iqbal (2017) explained that the application of profit-loss sharing in Islamic financial intermediation may create a more stable economy, minimizing the use of aggregate money demand for inessential and unproductive activities. The improved efficiency and equal distribution of resources as well as the reducing macroeconomic imbalances could cause inflation. The lack of alternative fund allocation and relatively high-risk burden with the profit-loss sharing system have smaller ratio of non-performing financing in Islamic banks than conventional banks. Concurrently, the asset growth in the long-run will result in credit risk, but this risk can be suppressed in the short-run by increasing asset. Increasing assets in the short-run may utilize the third party fund, one of which consists of unrestricted investment funds. The shared profit can turn into banks' asset if banks are good enough in handling investments.

Increasing third party fund through mutual assistance campaign with other organizations (such as non-bank financial services and mass organizations) may be utilized through crowdfunding and additional partnership contract to fund vulnerable bank customers, banks may act as an intermediary from those organizations and distribute funding, banks may also entice funder with installment refund in the long run. Supporting Sumarni (2020) who revealed that a lot of mass organizations are doing crowdfunding for the pandemic relief programs. Partnering with Islamic cooperatives may also become a way for cooperatives to provide easy installment payment procedures in accordance with the agreement between the two parties (Hidayat et al., 2020). 
Islamic Commercial Banks have strategic importance in competitive advantage and correlates with customers, namely the halal value. This kind of intangible asset can be utilized to build banks' image and customers' trust, especially in the Muslim community which is a considerable market potential for Islamic banks as customer trust is considered as a valuable asset. Trust is the basic relationship foundation between banks and customers as religious commitment have a significant relationship to loyalty and the decision to transact in Islamic banking services (Sodikin, 2020).

Another solution is the development of advanced technology as mobile banking system is not well optimized even though the coverage scope is good and giving easier banking access. The presence of internet banking or electronic banking facilities will reduce operational costs and increase banks' profitability, providing convenience to customers through the ease and speed of conducting transactions (Stoica et al, 2015). However, several mobile banking apps are not lightweight and incompatible with older mobile devices, suggesting code problems but there is a room for tweaking. User accessibility also have to be advertised and promoted, as older aged people would prefer to physically go to banks than using mobile banking, giving tutorials and follow-ups may become an answer to this problem. Connection issues also need to be improved especially in rural areas or cities with high population density. Mobile banking products can be innovated with online alms and donations from customers to those in need and feature of giving merchandise, discount, or cashback in return for customers' donations.

For Islamic Commercial Banks which considered as having low stability may utilize better specification for customer funding, as the level of credit risk happening now is the consequence of the credit risk level in the past (Iqbal, 2017), this condition puts the importance of Sharia Supervisory Board (SSB) core competency. Products of Islamic banking also contribute to the risk level as murabaha has been the dominating product on the financing side. Shifting the major focus of Islamic banks into more risk-sharing products such as musarakah and mudarabah may be utilized to absorb and to reduce potential risks (Hidayat et al., 2020).

Furthermore, POJK No.18/POJK.03/2020 regulates the stability of the financial system especially for banks and the economic slowdown threat as a result of the Covid-19 pandemic. The regulation offered a solution on banks to conduct and/or accept merger, consolidation, acquisition, and/or integration. This solution may be acceptable for banks which have high risks and liquidity problem. As stated by Widarjono (2020), the stability of Islamic banks is greatly influenced by the size of banking assets and capital adequacy, as greater assets signify greater stability. Therefore, increasing equity is vital to maintain the stability of Islamic banks.

Government support in the banking stability is summarized by Ningsih \& Mahfudz (2020), Indonesia Financial Services Authority (OJK) issued the National Economic Stimulus as Countercyclical Policy on the Spread of Coronavirus Disease 2019 in the POJK No.11/POJK.03/2020. The stimulus program concerning the financing quality policy is based only on the compliance of principal payment and margin on funding (amounted to ten billion Rupiahs) and the funding restructuring scheme. It must be understood that the term 'restructuring' is the loan repayment scheme, not the elimination of the repayment which gives leniency to loan repayment through a relief program. This program took effect in 2020 until 2021, but the implementation is done by each bank's discretion.

The Government Law No. 33 of 2020 on Implementation of LPS Authority in the framework of Handling Financial System Stability Problems, concerns the role of Indonesia Deposit Insurance Corporation (LPS) to prepare, supervise, and increase the early involvement intensity on banks' solvability problems, so the role of LPS will be forward-looking. The LPS will cooperate with OJK to oversee banks' solvability, to prevent and to guide failed banks. The regulations above can be seen as the government's support on the banking industry to reduce banking risks.

In this crisis time, banks and Islamic financial institutions may utilize their capital as financing by giving qard al-hasan loan and it will not affect Islamic financial institutions' liquidity as they are expected to be paid soon. Another source of finance for qard al-hasan loan is the charity amount received by Islamic banks during murababa financing. As these funds are 
earmarked and cannot be used for any other purpose withou permission from the client, banks may utilize qard al-hasan funds during this pandemic to prevent businesses from getting bankrupt. Qard al-basan is a loan given by the first party to the second party without expectation of any reward. It is served as a bailout fund for a short period of time. This instrument may reduce banks and financial services risk possibility on money rush or liquidity run (Sodikin, 2020).

Banks may also consider their own provision on expected credit losses (ECL) as the governmental support may have a certain time lag and the liquidity crunch will come faster than the government's incentive. In a different perspective, as the repayments are relaxed and extended, banks may defer their profit-taking activities in a period of time with bond as collateral to all related parties, ensuring banks' profit earnings. However, as explained by Ahn \& Le (2019), this perspective can only be achieved under supervisory clarity on customers' credit history, defining customers who had received deferment or restructuring without affecting customers' credit standing

To summarize, the projection on Indonesian Islamic Commercial Banks is looking bright over Covid-19 pandemic time, looking through viewpoints from related institutions, banks, regulation, government, and public, even though there are several things that need to be improved. Furthermore, all parties must cooperate with each other to survive through this pandemic condition.

\section{Conclusion}

The Intermediary function of Islamic Commercial Banks is one of the leading industries in the financial sector. Hence an assessment on efficiency and stability of Islamic banks becomes urgent in this period of the Covid-19 pandemic. The DEA model is used for output orientation, while the VRS and CRS models are used to evaluate the efficiency and stability. This study also used panel ARDL to project the short-run and long-run effect of the stability and efficiency variables. Results of the DEA in the CRS model found that BAS has high efficiency and stability. BRIS, BMI, BVS, BPD NTBS, and BTPNS have high efficiency but low stability. BSM, BNIS, BCAS, and BMS have low efficiency and high stability. BPS, BSB, BJBS, and MS have low efficiency and stability. The VRS model results found that BSM, BRIS, BMI, BPD NTBS, and BAS have high efficiency and stability. BVS and BTPNS have high efficiency but low stability. BNIS and BSB have low efficiency and high stability. BPS, BSB, BMS, BJBS, and MS have low efficiency and stability. The panel ARDL results found that third party fund, operational expenses, and total financing have stable long-run effect in both models. While in the short-run, only operational expenses have significant positive effect on operational earning, and only total financing have significant positive effect on total assets.

Banks may shift into other minority products such as mudarabah, musarakah, and qard alhasan, replacing the focus from the murabaha financing to mitigate the banking risks. Absorbing workforces as marketing representatives, utilizing cooperative agreements, crowdfunding, improving banking technology, creating provisions on expected credit loss, and deferring profit may be used as strategies for banks to stay survive and resilient through the Covid-19 period. Results of this study may be used for academicians to further assess the stability and efficiency in the pandemic period. For banks, the results can be used for internal evaluation and product innovation. For policymakers, the results of this study can be utilized to formulate the right strategy in the Covid-19 era.

\section{Acknowledgements}

The authors are highly grateful for feedbacks and insights from P3EI - IEFBC UII referees, JEKI editor, article reviewers, and lecturers and colleagues of Islamic Economics UNAIR

\section{Author Contributions}

Conceptualization: M. Fikri Himmawan and Novian Abdi Firdausi

Data curation: M. Fikri Himmawan 
Formal analysis: Novian Abdi Firdausi

Investigation: M. Fikri Himmawan

Methodology: M. Fikri Himmawan and Novian Abdi Firdausi

Project administration: M. Fikri Himmawan

Supervision: Novian Abdi Firdausi

Validation: Novian Abdi Firdausi

Visualization: M. Fikri Himmawan

Writing - original draft: Novian Abdi Firdausi

Writing - review \& editing: Novian Abdi Firdausi

\section{References}

Ahn, H., \& Le, M. H. (2014). An insight into the specification of the input-output set for DEAbased bank efficiency measurement. Management Review Quarterly, 64(1), 3-37. https://doi.org/10.1007/s11301-013-0098-9

Alfarisi, M. F., \& Lukman S. (2019). Measuring efficiency of Islamic banks: Evidence from Indonesia. Jurnal Ekonomi \& Keuangan Islam, 5(1), 1-9. http://dx.doi.org/10.20885/jeki.vol5.iss1.art1

Anwar, M. (2016). The efficiency of banks in Indonesia: Sharia vs. conventional banks. Buletin Ekonomi Moneter Dan Perbankan, 18(3), 307-332. https://doi.org/10.21098/bemp.v18i3.552

Attard, J. (2019). Public debt and economic growth nexus: A dynamic panel ARDL approach. MPRA Paper, 96023. Retrieved from https://mpra.ub.uni-muenchen.de/96023/

Banker, R. D., Charnes, A., \& Cooper, W. W. (1984). Some models for estimating technical and scale inefficiencies in data envelopment analysis. Management Science, 30(9), 1078-1092. https://doi.org/10.1287/mnsc.30.9.1078

Bardi, W., Ayouni, S. E., \& Hamdaoui, M. (2019). Are structural policies in countries bordering mediterranean appropriate to economic convergence: Panel ARDL application. Cogent Economics \& Finance, 7(1). https://doi.org/10.1080/23322039.2019.1636496

Charnes, A., Cooper, W. W., \& Rhodes, E. (1978). Measuring the efficiency of decision making units. European Journal of Operational Research, 2(6), 429-444. https://doi.org/10.1016/0377-2217(78)90138-8

Coelli, T., Rao, D. S. P., \& Battese, G. E. (1998). An introduction to efficiency and productivity analysis. Springer US. https://doi.org/10.1007/978-1-4615-5493-6_2

Fama, E. F. (1980). Banking in the theory of finance. Journal of Monetary Economics, 6(1), 39-57. https://doi.org/10.1016/0304-3932(80)90017-3

Farrell, M. J. (1957). The measurement of productive efficiency. Journal of the Royal Statistical Society. Series A (General), 120(3), 253-290. https://doi.org/10.2307/2343100

Fauzi, M. (2018). Efisiensi Bank Pembiayaan Rakyat Syariah (BPRS) di provinsi Jawa Tengah. Junral Ekonomi \& Keuangan Islam, 4(1), 31-40. http://dx.doi.org/10.20885/jeki.vol4.iss1.art4

Hidayat, S. E., Farooq, M. O., \& Alim, E. A. (2020). Impact of the Covid-19 outbreak on Islamic finance in the OIC countries. Retrived from https://knks.go.id/storage/upload/1591090473b71788507b33ad61531b0705ed42b4269a8a994b.pdf

Iqbal, M. (2017). Perbandingan pengelolaan risiko kredit perbankan syariah dan perbankan konvensional. Jurnal Keuangan Dan Perbankan, 21(3), 481-497. https://doi.org/10.26905/jkdp.v21i3.1318

Lu, W. C. (2019). The role of macroeconomic development on carbon emissions for 15 Asian 
countries: Panel ARDL approach. International Journal of Global Warming, 17(2), 127-141. https://doi.org/10.1504/IJGW.2019.097857

Magweva, R., \& Sibanda, M. (2020). Inflation and infrastructure sector returns in emerging markets panel ARDL approach. Cogent Economics \& Finance, 8(1), 1-17. https://doi.org/10.1080/23322039.2020.1730078

Mokhtar, H. S. A., Abdullah, N., \& Al-Habshi, S. M. (2006). Efficiency of Islamic banking in Malaysia: A stochastic frontier approach. Journal of Economic Cooperation, 27(2), 37-70. Retrieved from https://jecd.sesric.org/pdf.php?file=ART06010102-2.pdf

Ningsih, M. R., \& Mahfudz, M. S. (2020). Dampak pandemi Covid-19 terhadap manajemen industri perbankan syariah: Analisis komparatif. Point, 2(1), 1-10. https://doi.org/10.46918/point.v2i1.576

Offiong, A. I., \& Egbuka, N. (2017). The Efficency of loan recovery rate in deposit money banks in Nigeria. Journal of Finance and Bank Management, 5(2), 40-49. https://doi.org/10.15640/jfbm.v5n2a4

OJK. (2020). Statistik Perbankan Syariah April 2020 (Issue April 2020). Otoritas Jasa Keuangan. Retrieved from https://www.ojk.go.id/id/kanal/syariah/data-dan-statistik/statistikperbankan-syariah/Documents/Pages/Statistik-Perbankan-Syariah---April-2020/SPS April 2020.pdf

Pesaran, M. H. (2007). A simple panel unit root test in the presence of cross-section dependence. Journal of Applied Econometrics, 22(2), 265-312. https://doi.org/10.1002/jae.951

Pesaran, M. H., Shin, Y., \& Smith, R. P. (1999). Pooled mean group estimation of dynamic heterogeneous panels. Journal of the American Statistical Association, 94(446), 621-634. https://doi.org/10.1080/01621459.1999.10474156

Rodoni, A., Salim, M. A., Amalia, E., \& Rakhmadi, R. S. (2017). Comparing efficiency and productivity in Islamic banking $\square$ : Case study Indonesia, Malaysia and Pakistan. $\mathrm{Al}$ Iqtishad: Journal of Islamic Economics, 9(2), 227-242. https:/ /doi.org/10.15408/aiq.v9i2.5153

Sodikin, M. (2020). Competitive advantages of sharia banks: Role of Ihsan behavior and digital marketing in new normal. Journal of Digital Marketing and Halal Industry, 2(1), 1-14. https://doi.org/10.21580/jdmhi.2020.2.1.5769

Stoica, O., Mehdian, S., \& Sargu, A. (2015). The impact of internet banking on the performance of Romanian banks: DEA and PCA approach. Procedia Economics and Finance, 20, 610-622. https://doi.org/10.1016/S2212-5671(15)00115-X

Sulaeman. (2020, October 13). Merger, bank syariah BUMN siap tawarkan layanan keuangan syariah lengkap di satu atap. Merdeka.Com. Retrieved from http://merdeka.com/uang/merger-bank-syariah-bumn-siap-tawarkan-layanan-keuangansyariah-lengkap-di-satu-atap.html.

Sumarni, Y. (2020). Manajemen ekonomi Islam dalam menangani pandemi Coronavirus disease (Covid-19) di Indonesia. Jurnal BAABU AL-ILMI: Ekonomi dan Perbankan Syariah, 5(1), 117-126. https://doi.org/10.29300/ba.v5i1.3123

Widarjono, A. (2020). Stability of Islamic banks in Indonesia: Autoregressive Distributed Lag approach. Jurnal Keuangan dan Perbankan, 24(1), 40-52. https://doi.org/10.26905/jkdp.v24i1.3932

Yulita, I., \& Rizal, S. (2016). Islamic banking efficiency: Comparative studies between Malaysia and Indonesia. Signifikan: Jurnal Ilmu Ekonomi, 5(1), 31-50. https://doi.org/10.15408/sjie.v5i1.3129 